\section{Dominika Dörre-Kolasa}

Uniwersytet Jagielloński
https://orcid.org/0000-0002-4134-741X

\title{
ADMINISTRATOR DANYCH OSOBOWYCH W ZBIOROWYM PRAWIE ZATRUDNIENIA
}

\author{
Abstract \\ Personal data controller in collective employment law
}

Entering into force of the GDPR was an event that equally affected both employers and trade unions. In the course of practical implementation of provisions of law regarding personal data protection the main focus was put on employers who traditionally are seen as having bigger influence on factual and legal situation of employees. Trade unions seem to have overlooked the fact that they also process wide range of personal data of their members, often of very sensitive character. This article is an analysis of legal position of trade unions in relation of processing personal data with special emphasis put on cooperation with employers and employees in performing their statutory obligations. Clear assignment of position of data controller to trade union creates issues due to the wording of provisions of the GDPR. The same problem is present in case of different tiers of trade unions, especially those of regional or national range. However, function and role of trade unions allow to indicate them as data controllers of their members. In this paper the Author analyses legal bases for processing personal data by trade unions and determines transfers of personal data within trade unions and between trade unions and employers. Finally, the Author verifies documentation used by chosen representative trade unions in Poland in order to determine how trade unions themselves approach the issue of correct establishment of their position in processing personal data and how they apply provisions on personal data protection in practice.

Słowa kluczowe: RODO, zbiorowe prawo zatrudnienia, administrator danych osobowych, związek zawodowy

Keywords: GDPR, collective employment law, data controller, trade union

ASJC: 3308, JEL: K31

\section{Uwagi wstępne}

Niegasnące zainteresowanie tematyką ochrony danych osobowych, od momentu rozpoczęcia stosowania rozporządzenia Parlamentu Europejskiego i Rady (UE) 2016/679 z dn. 27 kwietnia 2016 r. w sprawie ochrony osób fizycznych w związku z przetwarzaniem 
danych osobowych i w sprawie swobodnego przepływu takich danych oraz uchylenia dyrektywy 95/46/WE (Dz.Urz. UE L 2016, nr 119, dalej: „RODO”) powoduje, iż coraz większa liczba przedstawicieli różnych dziedzin prawa prezentuje w literaturze własne, niejednokrotnie kontrowersyjne i wzajemnie się wykluczające poglądy na temat fundamentalnych pojęć i zasad ochrony danych osobowych.

Odpowiedzialne prowadzenie dyskursu wymaga jednak pogłębionych analiz, znacznie wykraczających poza przepisy RODO oraz ich wykładnię polegającą na porównaniu poszczególnych wersji językowych tego aktu. Ochrona danych osobowych, wbrew ogólnemu odczuciu społecznemu, nie rozpoczęła się z dn. 25 maja 2018 r. Już w latach 70. XX w. zaczęły się pojawiać pierwsze akty prawne regulujące tę tematykę. Powszechnie uznawanym głównym powodem zainteresowania regulacją ustawową przetwarzania danych osobowych był postęp technologiczny i odchodzenie od tradycyjnych „manualnych" metod przetwarzania na rzecz systemów informatycznych (Barta, Fajgielski, Markiewicz 2007, s. 50-51). Warto także przypomnieć, że już Konwencja o ochronie praw człowieka i podstawowych wolności z dn. 4 listopada 1950 r. (Dz.U. 1993, nr 61, poz. 284) miała swój jakże istotny wpływ na wzmocnienie rangi ochrony prawa do prywatności, z którym ściśle powiązana jest ochrona danych osobowych. Na gruncie prawa międzynarodowego podstawową regulacją poświęconą ochronie danych osobowych stanowi Konwencja nr 108 Rady Europy z dn. 28 stycznia 1981 r. (Dz.U. 2003, $\mathrm{nr} 3$, poz. 25). Znaczące rozbieżności, jakie pojawiły się w regulacjach wewnętrznych państw sygnatariuszy konwencji (Mednis 1997, s. 32), w zestawieniu ze wzrastającą potrzebą pojawienia się regulacji zmierzającej do pogodzenia dwóch na pozór wykluczających się wartości - prawa do ochrony prywatności oraz konieczności swobodnego przepływu danych - doprowadziły do wydania dyrektywy 95/46/WE Parlamentu Europejskiego i Rady z dn. 24 października 1995 r. w sprawie ochrony osób fizycznych $\mathrm{w}$ zakresie przetwarzania danych osobowych oraz swobodnego przepływu tychże danych (Dz.Urz. UE L 1995, nr 281).

Podstawowe pojęcia i zasady ochrony danych osobowych, a także prawa podmiotów danych, dostrzeżone i jakże żywiołowo wykładane w ostatnim roku, po rozpoczęciu stosowania RODO, w dużej mierze zostały ukształtowane kilkadziesiąt lat temu.

Wymienione powyżej akty prawne, które tworzyły fundamenty ochrony danych osobowych, powinny być brane pod uwagę podczas prowadzonych analiz i formułowanych kategorycznych niekiedy poglądów doktryny. Tylko wnikliwa analiza kluczowych pojęć, którymi będziemy się posługiwać, wsparta solidną podbudową teoretyczną uwzględniającą dotychczasowy dorobek tej dziedziny prawa, pozwoli na formułowanie wartościowych merytorycznie wniosków i stawianie określonych tez w sposób odpowiedzialny. W przeciwnym razie będziemy bazować jedynie na intuicjach autorów, negacji doczasowego dorobku oraz argumentowania, opierając się na różnicach między poszczególnymi wersjami językowymi. 


\section{Pojęcie administratora danych w przepisach prawa - elementy składowe definicji}

Rozpocząć należy od tego, iż w przypadku zbiorowych stosunków zatrudnienia mamy do czynienia z różnego rodzaju procesami przetwarzania danych osobowych, w ramach których można wyróżnić takie, które stanowią przejaw realizacji praw i obowiązków wynikających z przepisów prawa powszechnie obowiązującego, a także te, które mają swoje uzasadnienie w przepisach stanowionych przez uprawnione organy związkowe.

Wobec zgłaszanych w ostatnim czasie wątpliwości odnośnie do tego, czy w przypadku przetwarzania danych osobowych w wykonaniu obowiązku ustawowego mamy w ogóle do czynienia ze stosowaniem $\mathrm{RODO}^{1}$, zasadne jest przeanalizowanie treści obowiązującej regulacji, z uwzględnieniem perspektywy historycznej, a następnie przeniesienie tych rozważań na grunt przepisów zbiorowego prawa zatrudnienia w celu podjęcia próby odpowiedzi na pytanie, która struktura związkowa i w jakim zakresie będzie administratorem danych.

W kontekście powyższego zasadne wydaje się przypomnienie, iż już na gruncie poprzednio obowiązującej ustawy z dn. 29 sierpnia 1997 r. o ochronie danych osobowych (Dz.U. 2016, poz. 922 tekst jedn. ze zm., dalej: „ustawa o ochronie danych osobowych z 1997 r., „u.o.d.s. z 1997 r.”) w piśmiennictwie z zakresu ochrony danych osobowych prowadzona była analiza pojęcia administratora danych osobowych z perspektywy „decydowania o celach i środkach przetwarzania danych osobowych".

Wspólnym mianownikiem zaprezentowanych kierunków wykładni było stwierdzenie, iż sama definicja zawarta w tzw. słowniczku ustawowym (art. 7 pkt 4) poprzednio obowiązującej ustawy jest zbyt ogólna, a co za tym idzie - pozostałe cechy definicyjne administratora danych należy zrekonstruować na podstawie pozostałych przepisów ustawy (Drozd 2008, s. 62). Przyjrzyjmy się bliżej tej definicji, gdyż wydaje się, iż nie nastąpiła żadna rewolucja w tym zakresie w związku z rozpoczęciem stosowania RODO.

W poprzednio obowiązującym stanie prawnym przez administratora danych rozumiano organ, jednostkę organizacyjną, podmiot lub osobę, o których mowa w art. 3 ustawy z 1997 r., decydujące o celach i środkach przetwarzania danych osobowych. Zgodnie $\mathrm{z}$ tym przepisem zakresem podmiotowym stosowania ustawy objęte były organy państwowe, organy samorządu terytorialnego oraz państwowe i komunalne jednostki organizacyjne; a dodatkowo podmioty niepubliczne realizujące zadania publiczne, a także osoby fizyczne i osoby prawne oraz jednostki organizacyjne niebędące osobami prawnymi, jeżeli przetwarzają dane osobowe w związku z działalnością zarobkową, zawodową lub dla realizacji celów statutowych.

1 Tezę, zgodnie z którą „w zakresie, w jakim dane osobowe pracowników przetwarzane są w celu wykonania obowiązku ustawowego (prowadzenie dokumentacji pracowniczej), RODO nie ma zastosowana z tego powodu, że pracodawca nie spełnia przesłanek bycia administratorem", stawia Arkadiusz Sobczyk (2019, s. 22). Zdaniem tego autora, nie ziszcza się wówczas kryterium samodzielności ustalania celów i sposobów przetwarzania danych z uwagi na to, iż pracodawca wykonuje jedynie obowiązki nałożone przez ustawę. 
W dyrektywie 95/46/WE pod pojęciem administratora danych rozumiano zaś osobę fizyczną lub prawną, władzę publiczną, agencję lub inny organ, który samodzielnie lub wspólnie z innymi podmiotami określa cele i sposoby przetwarzania danych; jeżeli cele i sposoby przetwarzania danych są określane w przepisach ustawowych i wykonawczych lub przepisach wspólnotowych, administrator danych może być powoływany lub kryteria jego powołania mogą być ustalane przez ustawodawstwo krajowe lub wspólnotowe.

Zgodnie $\mathrm{z}$ art. 4 pkt 7 RODO administratorem danych jest osoba fizyczna lub prawna, organ publiczny, jednostka lub inny podmiot, który samodzielnie lub wspólnie z innymi ustala cele i sposoby przetwarzania danych osobowych.

W kontekście podniesionych powyżej wątpliwości niezbędne jest zwrócenie uwagi na drugą część definicji zawartej zarówno w RODO, jak też w dyrektywie 95/46/WE, pomimo iż zapisano ją nieco innymi słowami, przy zachowaniu tożsamości jej sensu. Zgodnie z nią:

[...] jeżeli cele i sposoby takiego przetwarzania są określone w prawie Unii lub w prawie państwa członkowskiego, to również w prawie Unii lub w prawie państwa członkowskiego może zostać wyznaczony administrator lub mogą zostać określone konkretne kryteria jego wyznaczania.

Podsumowując tę część wywodu, można w sposób uprawniony stwierdzić, iż określenie zarówno celów, jak i sposobów przetwarzania danych w przepisach prawa (wspólnotowego czy krajowego) nie niweczy statusu administratora danych, który może, choć nie musi być wyznaczony w przepisach, podobnie jak nie muszą, choć mogą być określone kryteria jego wyznaczania. Nawet jeśli status administratora danych jest regulowany prawem publicznym, to decyzje administratora danych dotyczące celów i środków przetwarzania danych są czynnościami o charakterze faktycznym, a nie władczym (Mednis 1999, s. 29; Sibiga 2003).

Można zatem stwierdzić, iż w zakresie pojęcia administratora danych osobowych RODO, w zestawieniu z dyrektywą 95/46/WE, niczego znacząco nie zmieniło. Pojęcie administratora danych występowało już na gruncie konwencji nr 108, z tą różnicą, iż był to jeszcze wówczas „,administrator zbioru danych”, a zatem sama regulacja ujęta była od strony przedmiotu - zbiór danych - podczas gdy dyrektywa 95/46/WE i ogólne rozporządzenie odnoszą tę definicję do działań odzwierciedlających cykl życia informacji, począwszy od jej pozyskania, a na zniszczeniu kończąc.

W opinii Grupy Roboczej ds. Ochrony Danych Art. 29 1/2010, przyjętej w dn. 16 lutego 2010 r. (00264/10/PL, WP 169, s. 5; dalej: „opinia 1/2010”) w kwestii pojęć „,administrator danych" i „przetwarzający” podkreślone zostało, iż w przypadku pojęcia administratora danych podstawową i najważniejszą rolą jest określenie, kto odpowiada za zgodność z zasadami ochrony danych i w jaki sposób osoby, których dane dotyczą, mogą w praktyce wykonywać swoje prawa. Zwrócono w ten sposób uwagę na bardzo istotny element, jakim jest powierzenie odpowiedzialności, który był podkreślany również w polskim piśmiennictwie na kanwie rozważań elementów definicyjnych administratora danych po wejściu w życie poprzednio obowiązującej ustawy (Drozd 2008, s. 62). 
Podobnie jak to miało miejsce pod rządami dyrektywy 95/46/WE, tak również na gruncie RODO definicja administratora składa się z trzech modułów:

1) personalnego: „osoba fizyczna lub prawna, organ publiczny, jednostka lub inny podmiot",

2) kontrolnego: określanego również mianem kontroli pluralistycznej z uwagi na użycie sformułowania „samodzielnie lub wspólnie z innymi”,

3) podstawowego: elementu odróżniającego administratora od innych podmiotów - „ustala cele i sposoby przetwarzania danych osobowych”.

Rozpoczynając od personalnego elementu definicji administratora, należy stwierdzić, iż uznanie jednostki organizacyjnej za administratora danych jest niezależne od posiadania przez nią jakiejkolwiek formy organizacyjnej, w szczególności od posiadania przez administratora osobowości prawnej. Z perspektywy przedmiotu analizy jest to dość istotne, gdyż posiadanie czy też brak osobowości prawnej poszczególnych struktur związkowych nie będzie stanowiło elementu delimitacyjnego.

\section{Właściwe rozumienie słowa „ustala” w definicji administratora danych}

Pośród elementów definicji administratora danych najwięcej kontrowersji i wątpliwości interpretacyjnych wywołuje ,ustalanie” celów i sposobów przetwarzania danych. Należy zauważyć, iż tam, gdzie w dyrektywie 95/46/WE i w RODO w tekstach oryginalnych występuje to samo słowo, a mianowicie determines, w tłumaczeniach tych aktów prawnych na język polski występują dwa różne słowa, a mianowicie „określa” w dyrektywie 95/46/WE oraz „ustala" w RODO. Wydaje się jednak, iż z uwagi na dominujące znaczenie dla wykładni tekstu oryginalnego wspomniane różnice nie powinny mieć żadnego wpływu na meritum, co pozwala na wykorzystanie wykładni tego elementu, ukształtowanej począwszy od lat 90 . XX w.

Wątpliwości, jakie się pojawiają, dotyczą stopnia samodzielności w ustalaniu owych celów i sposobów przetwarzania. Jeśli to nie podmiot, który dokonuje określonych czynności przetwarzania, ustala owe cele i sposoby samodzielnie i w sposób tylko przez siebie obrany, a jest mu to niejako odgórnie przez prawo narzucone, może nie być jasne, czy nadal możemy mówić o administratorze danych osobowych i procesach przetwarzania danych, do których RODO znajduje zastosowanie.

Zgodnie ze stanowiskiem wyrażonym w opinii 1/2010 zdolność „ustalania” może zostać nadana z mocy prawa i zwykle będzie wynikać $\mathrm{z}$ analizy elementów faktycznych lub okoliczności danego przypadku - należy przyjrzeć się konkretnym operacjom przetwarzania i zrozumieć, kto je określa, odpowiadając na pierwszym etapie na pytania: dlaczego dane przetwarzanie ma miejsce? I kto je rozpoczął? Bycie administratorem danych wynika zatem przede wszystkim z okoliczności faktycznej, w której podmiot podjął decyzję o przetwarzaniu danych osobowych dla własnych celów.

Powyższe będzie miało fundamentalne znaczenie dla prawidłowego określania, która struktura związkowa i w jakim zakresie będzie administratorem danych. Wszelkie pochopnie czynione w tym zakresie uogólnienia mogą okazać się błędne. 
Posiłkując się po raz kolejny opinią 1/2010, należy podkreślić, że podejście oparte na faktach determinuje postrzeganie pojęcia administratora danych w kategoriach funkcjonalnych. Polega to na tym, że obowiązki wynikające z RODO są przypisane tam, gdzie występuje tzw. faktyczny wpływ. Okoliczności, z których może wynikać ów faktyczny wpływ, w ocenie Grupy Roboczej ds. Ochrony Danych można sklasyfikować według następujących trzech kategorii sytuacji:

1. Kontrola wynikająca z wyraźnych kompetencji prawnych. Do tej sytuacji odnosi się druga część definicji administratora danych, a mianowicie przypadek, gdy administrator danych lub szczegółowe kryteria potrzebne do jego wyznaczenia są określane przez przepisy prawa krajowego lub wspólnotowego. Może to odbywać się przez bezpośrednie wskazanie, iż władze publiczne odpowiadają za przetwarzanie danych w ramach swoich obowiązków. Częściej jednak, jak wskazano w opinii 1/2010, ma miejsce sytuacja, w której przypisy prawa, zamiast bezpośredniego wyznaczania administratora lub określania kryteriów jego wyznaczenia, ustalają zadania lub nakładają obowiązki gromadzenia i przetwarzania niektórych danych.

2. Kontrola wynikająca z dorozumianej kompetencji. Ma ona miejsce w przypadku, gdy prawo nie ustala wyraźnie zdolności do określania celów i sposobów przetwarzania danych ani nie jest ona bezpośrednią konsekwencją wyraźnych przepisów prawnych, ale wynika w szczególności z utrwalonej praktyki dotyczącej różnych dziedzin (prawo cywilne, prawo handlowe, prawo pracy itd.). $\mathrm{W}$ takim przypadku w zidentyfikowaniu administratora danych pomogą istniejące tradycyjne role, które zwykle wiążą się z pewną odpowiedzialnością. Jako przykłady takich ról Grupa Robocza wskazuje pracodawcę w odniesieniu do danych dotyczących jego pracowników czy stowarzyszenie w odniesieniu do danych dotyczących jego członków lub osób wspierających.

3. Kontrola wynikająca $z$ faktycznego wpływu. Możemy o niej mówić, gdy funkcję administratora danych przydziela się na podstawie oceny okoliczności faktycznych. W wielu przypadkach będzie się to wiązało z oceną stosunków umownych między różnymi zaangażowanymi stronami. W praktyce może bowiem mieć miejsce sytuacja, gdy $\mathrm{w}$ umowie nie wspomniano, kto jest administratorem danych, ale zawarto elementy wystarczające do przydzielenia funkcji administratora danych stronie, która najwyraźniej pełni dominującą rolę $\mathrm{w}$ tym zakresie. Jak to zostało podkreślone w opinii 1/2010, w przypadku pojawienia się wątpliwości, który podmiot jest administratorem danych, poza warunkami umowy przydatne mogą się okazać takie elementy jak poziom faktycznej kontroli sprawowanej przez stronę, a w szczególności uzasadnione oczekiwania osób, których dane dotyczą. Jest to istotne zwłaszcza w tych przypadkach, w których do przetwarzania danych osobowych dochodzi w sposób niezgodny z prawem. Gdybyśmy bowiem ograniczyli przymiot administratora danych wyłącznie do procesów znajdujących oparcie w przepisach prawa, powszechnie uznawanej prawnie uzasadnionej praktyce czy zwyczaju, przetwarzanie danych przez określone podmioty niezgodnie z prawem uniemożliwiałoby egzekwowanie od nich wykonywania obowiązków, jakie RODO nakłada na administratora danych. Innymi słowy, w przypadku gdy dany podmiot decyduje się na niezgodne z prawem przetwarzanie danych, nie wyklucza go to 
z kręgu podmiotów, którym należy przyznać przymiot administratora danych z wszystkimi tego konsekwencjami.

\section{Administrator samodzielny czy współadministrator}

Z omawianym powyżej zagadnieniem łączy się element tzw. kontroli pluralistycznej. Chodzi tu mianowicie o sytuacje, gdy w przetwarzaniu danych osobowych uczestniczą różne podmioty, wzajemnie na siebie oddziałujące jednocześnie lub na różnych etapach „życia danych”. Odzwierciedla to element definicji: „samodzielnie lub wspólnie z innymi podmiotami”. Już na poziomie dyrektywy 95/46/WE dopuszczono możliwość działania co najmniej dwóch podmiotów na zasadzie współadministrowania danymi, co odzwierciedlał wspomniany fragment definicji. Do polskiej ustawy o ochronie danych osobowych z 1997 r. nie zostało to jednak implementowane. W tym więc zakresie dopiero rozpoczęcie stosowania RODO pozwala na analizowanie również tego aspektu z perspektywy skompilowanych niejednokrotnie w praktyce procesów przetwarzania danych (Gałęzowska 2019, s. 80-85).

W RODO, co więcej, po raz pierwszy zostało odrębnie zdefiniowane pojęcie współadministatora danych. Zgodnie z art. 26 jeżeli co najmniej dwóch administratorów wspólnie ustala cele i sposoby przetwarzania, są oni współadministratorami.

Niejednokrotnie relacje współadministrowania są trudne do oceny i dotyczą wielu złożonych aspektów przetwarzania. W tym kontekście każdorazowo należy przyjrzeć się poszczególnym stopniom, w jakich różne podmioty mogą oddziaływać na siebie i być ze sobą powiązane. Samo występowanie „łańcucha”, w którym dane są przekazywane pomiędzy poszczególnymi podmiotami, nie oznacza jeszcze, iż mamy do czynienia ze współadministrowaniem.

Poczynione powyżej uwagi nie mają jednak wyłącznie ogólnoteoretycznego znaczenia. Uznanie, iż w konkretnym przypadku mamy do czynienia ze wspólnym ustalaniem celów i sposobów przetwarzania, nie może się bowiem odbywać w sposób dowolny. W art. 26 RODO wprowadzone zostało wyraźne zobowiązanie do odpowiedniego podziału obowiązków między współadministratorami. Współadministrowanie wymaga ustalenia zasad realizacji praw osób, których dane dotyczą, oraz odpowiedniego podziału obowiązków i odpowiedzialności między współadministratorami w postaci wspólnych uzgodnień. Zasadnicza treść tych uzgodnień powinna być, co więcej, udostępniana podmiotom, których dane dotyczą.

\section{„Cele i sposoby przetwarzania” w definicji administratora danych}

Określenie „celu” przetwarzania powinno się odnosić do oczekiwanego i zamierzonego rezultatu (opinia $1 / 2010$ s. 14). Dla zapewnienia zgodności z RODO, tj. z art. 5 ust. 1 pkt b, cel ten powinien być konkretny, wyraźny i prawnie uzasadniony. Co do 
zasady - dane nie powinny być przetwarzane dalej w sposób niezgodny z tymi pierwotnymi celami.

Określanie „sposobów” należy interpretować szeroko. Mieszczą się w tym kwestie zarówno techniczne, jak i organizacyjne (np. rodzaj sprzętu, oprogramowania, stosowana forma zabezpieczenia przed dostępem osób nieupoważnionych, utratą danych), które niekiedy mogą być scedowane na podmioty przetwarzające dane w imieniu administratora, tzw. podmioty przetwarzające. Zasadnicze elementy określania „sposobów, tj. zakresu danych osobowych («jakie dane», «jakich podmiotów danych»), okresu przetwarzania danych, a także tego, kto ma dostęp do przetwarzanych danych", w tradycyjny i nieodłączny sposób określa wyłącznie administrator danych.

Podsumowując tę część rozważań, należy stwierdzić, iż pojęcie administratora danych jest autonomiczne w tym znaczeniu, że należy je interpretować głównie według wspólnotowych przepisów o ochronie danych. Równocześnie pojęcie to jest funkcjonalne w tym znaczeniu, że ma na celu przydzielanie zadań tam, gdzie występuje faktyczny wpływ, a zatem opiera się raczej na analizie okoliczności faktycznych niż na analizie formalnej.

\section{Podmiot „związkowy” a administrator danych osobowych}

Przenosząc poczynione powyżej uwagi na grunt przepisów zbiorowego prawa pracy oraz procesów przetwarzania danych, jakie zachodzą w ramach zbiorowych stosunków zatrudnienia, należy rozpocząć od elementu personalnego definicji administratora, który nie powinien przysparzać większych problemów interpretacyjnych. Uznanie jednostki organizacyjnej za administratora danych jest bowiem niezależne od posiadania przez nią jakiejkolwiek formy organizacyjnej, w szczególności od posiadania przez administratora osobowości prawnej.

W przypadku struktur związkowych, zgodnie z art. 13 pkt 7 ustawy z dn. 23 maja $1991 \mathrm{r}$. o związkach zawodowych (Dz.U. 2019, poz. 263 tekst jedn., dalej: „ustawa o związkach zawodowych”, „u.z.z."), statuty związków powinny wskazywać, które z jednostek organizacyjnych związku mają osobowość prawną. Nieposiadanie osobowości prawnej nie stanowi jednak przeszkody dla uznania danej jednostki organizacyjnej związku za administratora danych osobowych.

Jeżeli zaś chodzi o „określanie celów i sposobów przetwarzania danych”, to z poczynionych powyżej wywodów o charakterze teoretycznym wynika, iż nie stoi na przeszkodzie uznaniu danego podmiotu za administratora danych osobowych okoliczność przetwarzania danych $\mathrm{w}$ ramach realizacji praw i obowiązków wynikających z przepisów powszechnie obowiązującego prawa. W przypadku struktur związkowych $\mathrm{z}$ tego typu sytuacjami będziemy mieli do czynienia w przeważającej większości przypadków. Zarówno ustawa z dn. 26 czerwca 1974 r. - Kodeks pracy (Dz.U. 2018, poz. 917 tekst jedn. ze zm., dalej: „Kodeks pracy”), jak też ustawa o związkach zawodowych nakładają na określone formy prawne organizacji związkowych szereg obowiązków lub przyznają im uprawnienia, dla których niezbędne jest przetwarzanie danych osobowych. 
Z procesami przetwarzania danych będziemy mieli do czynienia również w przypadku realizacji celów statutowych.

Analiza przepisów zbiorowego prawa zatrudnienia pozwala na w miarę jednoznaczne określenie formy organizacyjno-prawnej struktury związkowej, której przypisany jest konkretny zakres uprawnień i obowiązków, dla realizacji których dochodzi do różnego rodzaju procesów przetwarzania danych osobowych. W tym kontekście można wręcz stwierdzić, że prawo pracy wyznacza granicę udostępniania określonych danych w relacji między pracodawcą a organizacją związkową. Sytuacja znacznie bardziej się komplikuje, wówczas gdy z uwagi na samorządność i niezależność związków zawodowych statuty związków przenoszą kompetencje ustawowe na struktury niższego szczebla, a także samodzielnie określają poszczególne kompetencje, które możemy objąć kategorią realizacji celów statutowych w ścisłym tego słowa znaczeniu; mam tu na myśli przykładowo organizowanie pomocy finansowej dla swoich członków. Procesy te wymagają, w mojej ocenie, bacznej uwagi władz związkowych, gdyż stosowanie RODO wymaga bezwzględnego przestrzegania zasad przetwarzania danych wynikających z przepisów ogólnego rozporządzenia. Organizacje związkowe będą w szczególności obowiązane do zweryfikowania stosowanych od lat dokumentów z uwzględnieniem zasady ograniczenia celu, minimalizacji danych, a także - co może okazać się niezwykle skomplikowane - zdefiniowania zasad retencji danych.

Warto $\mathrm{w}$ tym miejscu przypomnieć, iż zgodnie $\mathrm{z}$ definicją zawartą $\mathrm{w}$ art. 4 pkt 2 RODO pod pojęciem przetwarzania danych osobowych rozumie się operację lub zestaw operacji wykonywanych na danych osobowych lub zestawach danych osobowych w sposób zautomatyzowany lub niezautomatyzowany, takich jak: zbieranie, utrwalanie, organizowanie, porządkowanie, przechowywanie, adaptowanie lub modyfikowanie, pobieranie, przeglądanie, wykorzystywanie, ujawnianie przez przesłanie, rozpowszechnianie lub innego rodzaju udostępnianie, dopasowywanie lub łączenie, ograniczanie, usuwanie lub niszczenie.

\section{Zakres danych osobowych przetwarzanych w zbiorowym prawie zatrudnienia}

Za dane osobowe uważa się wszelkie informacje o zidentyfikowanej lub możliwej do zidentyfikowania osobie fizycznej (art. 4 pkt 1 RODO). Danymi osobowymi, do których przetwarzania dochodzi w ramach zbiorowego prawa zatrudnienia, będą w pierwszej kolejności dane ujawniające przynależność do związków zawodowych. Należy podkreślić, iż z mocy art. 9 ust. 1 RODO dane ujawniające przynależność do związków zawodowych zostały zaliczone do tzw. danych szczególnej kategorii, których przetwarzanie jest co do zasady zabronione. Rozporządzenie ogólne utrzymało dotychczasowy model regulacji polegający na wyodrębnieniu katalogu danych, które z uwagi na swój szczególny charakter wymagają zastosowania podwyższonych standardów ochrony. 
Jak się powszechnie przyjmuje, przetwarzanie danych osobowych zaliczonych do szczególnej kategorii, a zatem w szczególności danych ujawniających przynależność do związków zawodowych, wiąże się ze zwiększonym ryzykiem naruszenia praw i wolności podmiotu danych. Ryzyko to, w ślad za treścią motywu 71 RODO, może w szczególności dotyczyć zjawiska dyskryminacji.

Zakaz przetwarzania danych osobowych ujawniających przynależność do związków zawodowych nie ma jednak bezwzględnego charakteru. Zostaje on w szczególności uchylony wówczas, gdy osoba, której dane dotyczą, wyraziła wyraźną zgodę na przetwarzanie tych danych osobowych w jednym lub kilku konkretnych celach, chyba że prawo Unii Europejskiej lub prawo państwa członkowskiego przewidują, iż osoba, której dane dotyczą, nie może uchylić tego zakazu.

Przymiot administratora danych $\mathrm{w}$ zbiorowych stosunkach zatrudnienia powinien być jednak, w mojej ocenie, rozpatrywany znacznie szerzej niż tylko w kontekście przetwarzania danych osobowych „ujawniających przynależność do związku zawodowego". Mam na myśli cały szereg obowiązków i uprawnień, które prawo pracy nakłada na określone struktury związkowe, co niejednokrotnie powoduje, iż dochodzi do przetwarzania danych osobowych innych aniżeli tylko informacji ujawniających „członkostwo” w danej organizacji związkowej.

W pierwszej kolejności należy zauważyć, iż związki zawodowe mogą względem pracodawcy reprezentować nie tylko swoich członków, ale także inne osoby. Aby tak się jednak stało, niezbędne jest uzyskanie przez związki określonych informacji od samych podmiotów danych, co z kolei będzie uprawniało je do określonych działań ze sfery indywidualnego prawa pracy.

Na podstawie art. 4 u.z.z. związki zawodowe reprezentują osoby wykonujące pracę zarobkową, a także inne osoby, którym z mocy art. 2 u.z.z. przysługuje prawo koalicji. Zgodnie $\mathrm{z}$ definicją zawartą $\mathrm{w}$ art. $1^{1}$ u.z.z. przez osobę wykonującą pracę zarobkową należy rozumieć pracownika lub osobę świadczącą pracę za wynagrodzeniem na innej podstawie niż stosunek pracy, jeżeli nie zatrudnia do tego rodzaju pracy innych osób, niezależnie od podstawy zatrudnienia, oraz ma takie prawa i interesy związane z wykonywaniem pracy, które mogą być reprezentowane i bronione przez związek zawodowy. Poza prawem do reprezentowania wyżej wymienionych osób związki zawodowe bronią ich godności, praw oraz interesów materialnych i moralnych - zarówno zbiorowych, jak też indywidualnych.

Konkretyzacja zasad związkowej reprezentacji znajduje się w art. 7 u.z.z., zgodnie z którym w zakresie praw i interesów zbiorowych związki zawodowe reprezentują wszystkie osoby, którym przysługuje prawo koalicji (art. 2 ust. 1 i 3-6 u.z.z.), niezależnie od ich przynależności związkowej, natomiast w sprawach indywidualnych dotyczących wykonywania pracy zarobkowej związki zawodowe reprezentują prawa i interesy swoich członków. Na wniosek niezrzeszonej osoby, której przysługuje wspomniane prawo koalicji, związek zawodowy może podjąć się obrony jej praw i interesów wobec pracodawcy.

Z ustawowym uprawnieniem do reprezentacji w sprawach indywidualnych członków związku oraz osób niezrzeszonych, których obrony związek podjął się na ich wniosek, 
nieodłącznie wiąże się przetwarzanie danych osobowych tych osób. Należy podkreślić, iż z dalszych przepisów ustawy o związkach zawodowych - mam tu na myśli art. 26 u.z.z. i kolejne - wynika, iż zasadnicza wiązka uprawnień i obowiązków ze sfery indywidualnego prawa pracy została zastrzeżona dla zakładowej organizacji związkowej. Oczywiste jest, że w mniejszych strukturach związkowych, zwłaszcza obejmujących zakresem swojego działania jednego pracodawcę, związek zawodowy, przy spełnieniu pozostałych kryteriów wynikających z ustawy (art. $25^{1}$ u.z.z.), będzie korzystał z uprawnień zakładowej organizacji związkowej.

W przypadku ogólnopolskich czy branżowych związków zawodowych zasadniczo z ich statutów będzie wynikało tworzenie tzw. jednostek podstawowych szczebla zakładowego i tylko one będą mogły zgodnie z prawem uczestniczyć w procesach przetwarzania danych, które swoje oparcie znajdują w przepisach ustawowych.

\section{Przetwarzanie danych osobowych w aspekcie współdziałania pracodawcy z zakładową organizacją związkową w sprawach indywidualnych}

Zgodnie $\mathrm{z}$ art. 30 ust. 3 u.z.z. w indywidualnych sprawach ze stosunku pracy, w których przepisy prawa pracy zobowiązują pracodawcę do współdziałania z zakładową organizacją związkową, przed podjęciem działania pracodawca jest obowiązany zwrócić się do tej organizacji o informację o pracowniku korzystającym z jej obrony. Nieudzielenie tej informacji w terminie 5 dni od dnia otrzymania przez zakładową organizację związkową wniosku zwalnia pracodawcę z obowiązku współdziałania z zakładową organizacją związkową w sprawach dotyczących tego pracownika. Z treści tego przepisu wynika, iż w celu wyłonienia właściwej zakładowej organizacji związkowej reprezentującej pracownika w sprawach indywidualnych, z którą prowadzona będzie konsultacja, we wskazanych w Kodeksie pracy sytuacjach pracodawca powinien wystąpić do wszystkich działających u niego pełnoprawnych organizacji zakładowych z zapytaniem, czy pracownik ten korzysta z ochrony związkowej. Celem takiego zwrócenia się pracodawcy o informację o pracownikach korzystających z obrony związku zawodowego jest uzyskanie wiedzy o tym, czy - a jeżeli tak, to który - związek zakładowy będzie uprawniony do występowania w obronie poszczególnych pracowników.

Z perspektywy zasad ochrony danych osobowych należy zwrócić uwagę na następujące zagadnienia. Po pierwsze pracodawca nie powinien zwracać się z pytaniem, czy konkretny pracownik ,jest członkiem” organizacji, gdyż przepisy prawa wyraźnie odnoszą się do osoby „korzystającej z obrony związkowej”. Jak to już zostało wskazane, zgodnie z treścią ust. 2 art. 30 u.z.z. każda osoba niezrzeszona w związku zawodowym wykonująca pracę zarobkową ma prawo do obrony swoich praw na zasadach dotyczących osób będących członkami związku. Do uzyskania wiedzy o tym, czy dany pracownik korzysta z obrony organizacji zakładowej, w sprawach indywidualnych nie będzie dla pracodawcy w żadnym wypadku niezbędna wiedza o tym, czy z ochrony tej korzysta 
z racji członkostwa w organizacji, czy też jest to pracownik niezrzeszony, który zwrócił się o ochronę i ją uzyskał.

Artykuł 30 ust. 3 u.z.z. nie stanowi zatem autonomicznej podstawy prawnej do uzyskania przez pracodawcę informacji ujawniającej członkostwo pracownika w związku zawodowym. Ujawnienie pracodawcy takiej informacji przez związek na wypadek potrzeby konsultacji w sprawach indywidualnych, w mojej ocenie, wymagałoby wyraźnej zgody podmiotu danych (zgodnie z treścią art. 9 ust. 2 pkt d RODO).

Podsumowując tę część rozważań, należy stwierdzić, iż nieuprawnione jest twierdzenie, zgodnie z którym w ramach procesu współdziałania pracodawcy w sprawach indywidualnych dochodzi do ujawnienia pracodawcy informacji o przynależności danej osoby fizycznej do związku zawodowego. Możemy wówczas mówić jedynie o uprawdopodobnieniu tego faktu, gdyż - jak wiadomo - również osoby niezrzeszone mogą być w tych sprawach reprezentowane.

Bez wątpienia odrębnymi administratorami danych uczestniczącymi w procesach konsultacji indywidualnych są pracodawca i zakładowa organizacja związkowa. Nie jest to, co więcej, uzależnione od tego, czy organizacja zakładowa posiada osobowość prawną, czy też nie została jej ona przyznana. Ponadto należy podkreślić, iż w ramach procesów konsultacyjnych pracodawca przekazuje organizacji szczebla zakładowego cały szereg informacji (danych osobowych dotyczących osób reprezentowanych), co wynika z określonych przepisów prawa pracy nakazujących obowiązek współdziałania między tymi podmiotami (np. art. 38, 52, 53, 112, 177 k.p.).

Jak wynika z powyższego, w omawianych sytuacjach przetwarzanie danych osobowych nie polega na „ujawnieniu” pracodawcy przynależności określonej osoby do związku zawodowego, a na udostępnieniu zakładowej organizacji związkowej informacji dotyczących reprezentowanej przez nią osoby ze sfery indywidualnej.

\section{Przetwarzanie danych osobowych ujawniających przynależność do związków zawodowych}

W art. 9 RODO, podobnie jak wcześniej w art. 10 dyrektywy 95/46/WE oraz w art. 27 u.o.d.s. z 1997 r., pośród danych osobowych wyższego stopnia ochrony prawnej wymienione zostały dane osobowe ujawniające przynależność do związków zawodowych. Prawodawca konsekwentnie posługuje się zwrotem „dane ujawniające”, z czego należy wnioskować, że danymi tej szczególnej kategorii będą zarówno informacje wprost stwierdzające, iż dana osoba jest członkiem organizacji związkowej, jak też informacje, z których przeciętny odbiorca może to „wyprowadzić z dużą dozą prawdopodobieństwa” (Barta, Fajgielski, Markiewicz 2007, s. 523). 


\section{Niezbędność przetwarzania do wypełnienia obowiązków i wykonywania szczególnych praw w dziedzinie prawa pracy, zabezpieczenia społecznego i ochrony socjalnej}

Na zasadzie wyjątku od zasady ogólnego zakazu przetwarzania danych osobowych ujawniających przynależność do związków zawodowych, zgodnie z treścią art. 9 ust. 2 lit. b, przetwarzanie tych jest jednak dopuszczalne, gdy jest niezbędne do wypełnienia obowiązków i wykonywania szczególnych praw przez administratora lub osobę, której dane dotyczą, w dziedzinie prawa pracy, zabezpieczenia społecznego i ochrony socjalnej, o ile jest to dozwolone prawem Unii Europejskiej lub prawem państwa członkowskiego, lub porozumieniem zbiorowym na mocy prawa państwa członkowskiego przewidującymi odpowiednie zabezpieczenia praw podstawowych i interesów osoby, której dane dotyczą.

W kontekście powyższej przesłanki uchylającej zakaz przetwarzania danych osobowych ujawniających przynależność do związków zawodowych należy wskazać, iż ustawa o związkach zawodowych przewiduje w kilku przepisach uprawnienia związkowe, dla skorzystania z których niezbędne jest ujawnienie pracodawcy informacji o „członkostwie”. Ma to miejsce wówczas, gdy wiąże się to z realizacją określonych uprawnień po stronie funkcyjnych działaczy związkowych, którym to uprawnieniom odpowiadają stosowne obowiązki lub ograniczenia po stronie pracodawcy. Wówczas mamy do czynienia $z$ udostępnieniem danych osobowych pomiędzy dwoma niezależnymi administratorami: odpowiednią strukturą związkową i pracodawcą, z których każdy realizuje własne cele, a ich „ustalenie” znajduje swoje oparcie w przepisach prawa.

W pierwszej kolejności należy wskazać, iż do ujawnienia pracodawcy informacji o przynależności określonej osoby do związku zawodowego będzie dochodziło w ramach realizacji prawa do urlopu bezpłatnego u tegoż pracodawcy w sytuacji powołania pracownika do pełnienia z wyboru funkcji związkowej poza zakładem pracy, jeżeli z wyboru wynika obowiązek wykonywania tej funkcji w charakterze pracownika. Do skorzystania z tegoż urlopu niezbędne jest zwrócenie się przez organizację związkową do pracodawcy ze stosownym wnioskiem. Od dn. 1 stycznia 2019 r. tryb udzielania urlopu bezpłatnego, o którym mowa w art. 25 ust. 1 u.z.z., oraz sposób postępowania w przypadku wygaśnięcia mandatu do pełnienia $z$ wyboru funkcji związkowej przez pracownika korzystającego z urlopu bezpłatnego, mając na względzie niwelowanie ujemnych następstw wynikających z pełnienia funkcji związkowej przez pracownika, a także zabezpieczenie potrzeb pracodawcy, reguluje rozporządzenie Rady Ministrów z dn. 3 grudnia 2018 r. w sprawie trybu udzielania urlopu bezpłatnego pracownikowi powołanemu do pełnienia $\mathrm{z}$ wyboru funkcji związkowej poza zakładem pracy oraz sposobu postępowania w przypadku wygaśnięcia mandatu do pełnienia $\mathrm{z}$ wyboru funkcji związkowej przez pracownika korzystającego z urlopu bezpłatnego (Dz.U. 2018, poz. 2358, dalej: „rozporządzenie z dn. 3 grudnia 2018 r.”). Zgodnie z $\$ 1$ powyższego rozporządzenia $\mathrm{z}$ wnioskiem o udzielenie urlopu bezpłatnego pracownikowi może wystąpić do pracodawcy właściwy statutowo organ organizacji związkowej, w której pracownik ma pełnić daną funkcję. W takiej sytuacji organizacja ta stanie się administratorem danych 
osobowych dotyczących zatrudnienia pracownika w zakresie wykraczającym poza samą kwestię członkostwa w związku zawodowym. Właściwy statutowo organ organizacji, w której pracownik ma pełnić funkcję, musi pozyskać od takiego pracownika informacje o pozostawaniu przez niego w zatrudnieniu u określonego pracodawcy, do którego będzie należało wystąpienie ze stosownym wnioskiem. W literaturze przedmiotu zwrócono uwagę, iż właściwym statutowo organem organizacji związkowej może być również każdy organ, który jest upoważniony do jej reprezentacji na zewnątrz (Książek 2019, s. 128). Ponownie w tym przypadku widzimy jakże charakterystyczną dla ruchu związkowego dużą dozę autonomii w określaniu przepływów danych osobowych, a także wskazywaniu podmiotów, które z ramienia związku są uprawnione do ich przetwarzania. Wyrażam obawę, iż organizacje związkowe nie dostrzegają w tym przypadku potrzeby uregulowania tych kwestii od strony formalnej, o czym będzie jeszcze mowa w dalszej części opracowania.

$\mathrm{Z}$ treści wniosku określonego $\mathrm{w} \$ 1$ pkt 3 rozporządzenia $\mathrm{z}$ dn. 3 grudnia $2018 \mathrm{r}$. pracodawca uzyska informację o okresie pełnienia $\mathrm{z}$ wyboru funkcji związkowej poza zakładem pracy, na który ma być udzielony urlop bezpłatny, a także o tym, że z wyborem wiąże się obowiązek wykonywania funkcji związkowej w charakterze pracownika. Zakres informacji pozyskiwanych przez pracodawcę jest zatem szerszy niż sam tylko fakt ujawnienia członkostwa w danej organizacji. Właściwy statutowo organ organizacji związkowej, na wniosek której udzielono pracownikowi urlopu bezpłatnego, niezwłocznie - nie później niż w terminie 7 dni od dnia wygaśnięcia mandatu pracownika do pełnienia $\mathrm{z}$ wyboru funkcji związkowej poza zakładem pracy - zawiadamia o tym pracodawcę.

Uzyskując wskazane $\mathrm{w}$ treści rozporządzenia informacje, pracodawca przetwarza je we własnym celu. Nie ma więc wówczas mowy o współadministrowaniu danymi pracownika korzystającego z urlopu bezpłatnego ani tym bardziej o powierzeniu ich przetwarzania. Ani pracodawca, ani organizacja związkowa nie mogą wykorzystywać uzyskanych danych osobowych w innych celach niż wskazane powyżej. Jeżeli takowa potrzeba jednak by się pojawiła, niezbędne będzie autonomiczne określenie celu takowego przetwarzania oraz ocena całego procesu z perspektywy art. 5 RODO.

$\mathrm{Na}$ szczeblu zakładowym pełnienie funkcji związkowej w zarządzie organizacji uprawnia działacza związkowego do zwolnienia z obowiązku świadczenia pracy, z zachowaniem prawa do wynagrodzenia lub bezpłatnie, w okresie kadencji na podstawie art. 31 u.z.z. (w zależności od liczebności organizacji związkowej - w pełnym lub niepełnym wymiarze).

Tryb udzielania tego zwolnienia i korzystania z niego określa rozporząadzenie Rady Ministrów z dn. 27 listopada 2018 r. w sprawie trybu udzielenia i korzystania ze zwolnienia z obowiązku świadczenia pracy na okres kadencji w zarządzie zakładowej organizacji związkowej przysługującego osobie wykonującej pracę zarobkową, sposobu ustalenia wysokości wynagrodzenia albo świadczenia pieniężnego przysługującego osobie w okresie zwolnienia od pracy oraz wynikających z tego tytułu uprawnień i świadczeń (Dz.U. 2018, poz. 2323). W płaszczyźnie podmiotowej zwolnienie od świadczenia pracy na mocy omawianej nowelizacji ma zastosowanie wobec osoby wykonującej pracę 
zarobkową. Na podstawie argumentu lege non distinguente uzasadniona wydaje się konstatacja, że dotyczy ono zarówno pracowników, jak i innych osób świadczących pracę za wynagrodzeniem (Baran 2019a, s. 206). Prawo do zwolnienia z obowiązku świadczenia pracy na podstawie art. 31 u.z.z. posiadają wszystkie kategorie osób wykonujących pracę zarobkową. Przysługują im stosowne do charakteru pracy uprawnienia lub świadczenia (art. 31 ust. 2 pkt 1 u.z.z.), w tym prawo do wynagrodzenia lub świadczenia pieniężnego, o ile zarząd zakładowej organizacji związkowej wystąpił z takim wnioskiem. Pracodawca zwalnia osobę wykonującą pracę zarobkową z obowiązku świadczenia pracy na okres kadencji w zarządzie zakładowej organizacji związkowej na podstawie wniosku zarządu tej organizacji zawierającego między innymi imię i nazwisko osoby wykonującej pracę zarobkową, której ma być udzielone zwolnienie z obowiązku świadczenia pracy na okres kadencji w zarządzie zakładowej organizacji związkowej; ponadto mają w nim być wskazane okoliczności uzasadniające udzielenie zwolnienia od pracy. Nie pozostawia więc najmniejszych wątpliwości, iż informacja o członkostwie w zarządzie organizacji zakładowej jest równoznaczna $\mathrm{z}$ informacją ujawniającą przynależność danej osoby do związku zawodowego. Co więcej, zarząd zakładowej organizacji związkowej jest obowiązany do niezwłocznego poinformowania pracodawcy o ustaniu okoliczności uprawniających osobę wykonującą pracę zarobkową do korzystania ze zwolnienia od pracy nie później niż w terminie 7 dni od dnia ich ustania. Wydaje się, że w celu realizacji powyższego obowiązku nie jest niezbędne przekazywanie pracodawcy szczegółowych informacji na temat przyczyn utraty uprawnienia do zwolnienia. W każdym razie organizacja powinna dokonać takowej oceny, mając na uwadze zasadę minimalizacji danych osobowych (art. 5 ust. 1 lit. c RODO).

Podobnie do ujawienia informacji o przynależności do związku zawodowego dochodzi w ramach realizacji gwarancji trwałości stosunku pracy członków zakładowej organizacji związkowej, o której mowa w art. 32 u.z.z. W ust. $9^{2}$ tego przepisu stwierdzono wyraźnie, iż zarząd zakładowej organizacji związkowej lub komitet założycielski zakładowej organizacji związkowej wskazują pracodawcy na piśmie osoby, których stosunek prawny podlega ochronie, przez podanie właściwych imion i nazwisk, a także czasu trwania ochrony. Zmiany we wskazaniu są dokonywane przez zarząd lub komitet założycielski zakładowej organizacji związkowej na piśmie w terminie 7 dni od dnia zaistnienia zmiany. Przetwarzanie wskazanych powyżej danych osobowych przez pracodawcę jest $\mathrm{z}$ jednej strony niezbędne do wypełnienia przez niego określonych obowiązków, wówczas gdy będzie zamierzał rozwiązać, wypowiedzieć czy też jednostronnie zmienić na niekorzyść osoby wykonującej pracę zarobkową warunki pracy lub wynagrodzenia, a zarazem jest niezbędne do wykonywania szczególnych praw przez osobę, której dane dotyczą, w dziedzinie prawa pracy. Przekazanie pracodawcy imiennej listy osób szczególnie chronionych wydaje się również obowiązkiem zarządu zakładowej organizacji związkowej.

W sposób zbliżony do wymienionych powyżej sytuacji należy ocenić regulację $\mathrm{z}$ art. $33^{1}$ ust. 1 u.z.z. Zgodnie $\mathrm{z}$ tym przepisem pracodawca na pisemny wniosek zakładowej organizacji związkowej i za pisemną zgodą osoby wykonującej pracę zarobkową 
jest obowiązany pobierać z wynagrodzenia tej osoby składkę związkową w zadeklarowanej przez nią wysokości. Pracodawca w ramach realizacji tego obowiązku wynikającego z przepisu prawa pozyska informację o przynależności związkowej. Uiszczanie składki jest jednym z podstawowych obowiązków członków związku zawodowego, którego zaniechanie może powodować utratę członkostwa na zasadach określonych w statutach związków. Pracodawca staje się w takiej sytuacji w ograniczonym zakresie administratorem danych osobowych ujawniających przynależność do związku zawodowego, ale przetwarzanie tych danych jest wyraźnie limitowane celem, jakim jest dokonywanie potrącenia $\mathrm{z}$ wynagrodzenia za pracę składki członkowskiej. W innym celu pracodawca nie może skorzystać z tej informacji. W szczególności, w mojej ocenie, nie jest dopuszczalne omijanie trybu zapytania $\mathrm{z}$ art. 30 ust. 3 u.z.z. w sytuacji, gdy pracodawca zamierza podjąć określone działania, co do których przepisy prawa pracy wymagają współdziałania z zakładową organizacją związkową reprezentującą pracownika.

$\mathrm{Z}$ uwagi na względy funkcjonalne $\mathrm{w}$ doktrynie prawa pracy za dopuszczalne uznane zostało dołączenie przez organizację związkową do wniosku o pobieranie składki członkowskiej listy członków związku, którzy wyrazili na to zgodę (Baran 2019a, s. 206). Zgoda osoby wykonującej pracę zarobkową nie musi bowiem zostać wyrażona w obecności przedstawiciela pracodawcy, wówczas gdy na oświadczeniu widnieje własnoręczny podpis takiej osoby wraz z określeniem wysokości składki. Rozwiązanie takie wydaje się najwłaściwsze także ze względu na ochronę danych osobowych. Udostępnienie pracodawcy danych osobowych ujawniających przynależność do związku zawodowego, w mojej ocenie, jest dopuszczalne tylko po uzyskaniu potwierdzenia od członków związku, iż wyrażają zgodę na pobieranie składki związkowej z ich wynagrodzenia przez pracodawcę. W praktyce stosunków przemysłowych jest nieraz silnie akcentowane, że z uwagi na jakość dialogu społecznego i napięcia na linii pracodawca-organizacja związkowa pracownicy chcą zachować anonimowość w zakresie swojej przynależności związkowej względem pracodawcy. Wyrażam pogląd, iż nie posiadając zgody od członka związku na potrącanie składki z jego wynagrodzenia, organizacja związkowa nie powinna uwzględniać takiej osoby we wniosku kierowanym do pracodawcy. W praktyce mogą bowiem wystąpić takie sytuacje, w których pracodawca uzyskałby informację o członkostwie danej osoby w organizacji związkowej z uwagi na umieszczenie jej we wniosku, mimo że pracownik nie wyraził pisemnej zgody na potrącanie składki. Za stosowaniem zaproponowanego powyżej rozwiązania przemawia zatem interes obydwu administratorów danych: pracodawcy i organizacji związkowej.

Należy również zwrócić uwagę na to, iż osoba wykonująca pracę zarobkową zawsze jest uprawniona do cofnięcia zgody na potrącenia, i to bez uzasadnienia. Tego rodzaju oświadczenie powinno ze względów dowodowych nastąpić na piśmie, choć również ustna dyspozycja powinna być dla pracodawcy wiążąca. Pracodawca nie jest ustawowo zobowiązany do przekazania organizacji związkowej informacji o decyzji członka związku w przedmiocie cofnięcia zgody na pobieranie składek (Baran 2019a, s. 206).

Wydaje się, iż organizacja związkowa jest uprawniona do tego, aby uzyskać od pracodawcy, na jej wniosek, informację o tym, od których pracowników jest pobierana składka 
związkowa. Przeciwny tok rozumowania uniemożliwiałby organizacji monitorowanie wywiązywania się przez jej członków z obowiązków statutowych z uwagi na stosowaną praktykę zbiorczych przelewów. Dostęp do tych danych powinien jednak odbywać się na zasadach określonych w art. 28 u.z.z. Organizacja nie jest jednak - w mojej ocenie - uprawniona do uzyskania informacji o konkretnych kwotach, które są potrącane z wynagrodzenia, a jedynie do uzyskania informacji o tym, że składka jest pobierana. Informacje przekazywane pracodawcy nie mogą bowiem dotyczyć statusu finansowego konkretnego pracownika lub innej osoby świadczącej pracę za wynagrodzeniem (Baran 2019b, s. 8). Informacja o wysokości pobranej i przekazanej składki nie jest niezbędna do prowadzenia działalności związkowej. W tych wszystkich sytuacjach, w których składka stanowi określony procent od wynagrodzenia, przez przekazanie takiej informacji pracodawca ujawniałby dane osobowe pracownika lub osoby świadczącej pracę za wynagrodzeniem bez podstawy prawnej. Nie jest oczywiście wykluczone, aby osoba taka wyraziła zgodę na przekazanie organizacji związkowej informacji o wysokości konkretnych kwot pobranych składek związkowych przy pełnej świadomości, iż może w ten sposób dojść do ujawnienia informacji o wysokości otrzymanego w poszczególnych miesiącach wynagrodzenia.

\section{Przetwarzanie w ramach wykonywania uprawnionej działalności o celach związkowych}

Zakaz przetwarzania danych osobowych ujawniających przynależność do związków zawodowych nie znajduje zastosowania w sytuacjach, gdy przetwarzania dokonuje się $\mathrm{w}$ ramach uprawnionej działalności prowadzonej z zachowaniem odpowiednich zabezpieczeń, w szczególności przez niezarobkowy podmiot o celach związkowych, pod warunkiem że przetwarzanie dotyczy wyłącznie członków lub byłych członków tego podmiotu lub osób utrzymujących z nim stałe kontakty w związku z jego celami oraz że dane osobowe nie są ujawniane poza tym podmiotem bez zgody osób, których one dotyczą (art. 9 ust. 2 pkt d RODO). Na podstawie tej przesłanki uchylającej zakaz przetwarzania nie będzie jednak dopuszczalne ujawnienie danych osobowych. Wówczas - jak to wynika wprost z treści przepisu - wymagana będzie zgoda podmiotu danych.

Wskazana powyżej przesłanka uchylająca zakaz przetwarzania danych jest wzorowana na poprzednio obowiązujących przepisach, a mianowicie na art. 8 ust. 2 lit. d dyrektywy 95/46/WE. Wykazuje również istotne podobieństwo do podstawy określonej w art. 27 ust. 2 pkt 4 u.o.d.s. z 1997 r., z tą istotną różnicą, że prawodawca unijny rozszerzył dopuszczalność przetwarzania danych o dane dotyczące „byłych członków”.

Warto wspomnieć, iż zarówno w poprzednim stanie prawnym, jak i obecnie w RODO jest wymagane, aby działalność niezarobkowego podmiotu o celach związkowych w zakresie przetwarzania danych osobowych dokonywana była z zachowaniem odpowiednich zabezpieczeń, a dane osobowe nie były ujawniane bez zgody osób, których dotyczą. Pierwszy z przywołanych tu wymogów oznacza konieczność stosowania przepisów 
RODO dotyczących zabezpieczenia przetwarzanych danych (określonych w art. 32 i innych przepisach komentowanego rozporządzenia), natomiast drugi wskazuje na swego rodzaju wewnętrzny charakter wykorzystania danych przez wskazaną w komentowanym przepisie grupę podmiotów - dane sensytywne nie powinny być ujawniane poza tym podmiotem (fundacją, stowarzyszeniem, kościołem itp.) bez zgody osoby, której dane dotyczą. Ostatni wymóg nie oznacza jednak, że przepisy szczególne nie mogą wprowadzić obowiązku ujawniania danych sensytywnych innym podmiotom (Fajgielski 2018, s. 209).

Zakresem podmiotowym omawianego wyjątku prawodawca wspólnotowy objął zarówno członków organizacji, byłych członków, jak też osoby utrzymujące stałe kontakty $\mathrm{z}$ takimi podmiotami. Nie będzie zatem stanowiła stałego kontaktu incydentalna korespondencja z daną organizacją (Barta, Fajgielski, Markiewicz 2007, s. 529), przykładowo za pomocą formularza udostępnionego na stronie internetowej.

Należy się zatem zastanowić, jak w ramach analizowanego wyjątku z perspektywy związkowej należy pozycjonować osoby ubiegające się o członkostwo w danej organizacji, które wypełniły deklarację członkowską, ale nie zostały jeszcze przyjęte. Nie mogą one być uznane za osoby utrzymujące stałe kontakty, gdyż można założyć z dużą dozą prawdopodobieństwa, że gdyby tak było, trudno byłoby znaleźć uzasadnienie dla pozostawania poza organizacją związkową. W literaturze przedmiotu został zaprezentowany pogląd, zgodnie z którym przetwarzanie danych osobowych osób ubiegających się o członkostwo w organizacji na podstawie przesłanki tej treści można by uznać za właściwe wówczas, gdy jest niemalże pewne przyjęcie określonej osoby w poczet członków (Drozd 2008, s. 169). W mojej ocenie - w takiej sytuacji nie ma jeszcze mowy o przetwarzaniu danych osobowych ujawniających przynależność do związków zawodowych, tak więc poruszanie się w obszarze zastosowania przesłanki uchylającej zakaz przetwarzania danych szczególnej kategorii może być wątpliwe. Zupełnie inaczej należy jednak zaklasyfikować przypadek, w którym zgodnie ze statutem organizacji związkowej członkostwo nabywa się z chwilą wypełnienia deklaracji i przekazania jej do właściwego podmiotu w strukturze organizacyjnej.

Właściwe zastosowanie analizowanej obecnie przesłanki uchylającej zakaz przetwarzania danych osobowych ujawniających przynależność do związków zawodowych wymaga zwrócenia uwagi na sposób, w jaki zgodnie ze statutami związków dochodzi do uzyskania członkostwa w danej organizacji. Sprawa ta na pozór mogłaby się wydawać oczywista - sprowadzalna do wypełnienia przez „kandydata na członka” deklaracji członkowskiej i jej przekazania do właściwego organu związkowego. W praktyce jednak w myśl zasady samorządności związków zawodowych zarówno statuty, jak i wydane na ich podstawie uchwały organów związkowych w sposób bardziej skomplikowany określają zasady nabywania i utraty członkostwa w organizacji ze szczególnym uwzględnieniem różnic wynikających z tego, czy mamy do czynienia z etapem tworzenia organizacji określonego szczebla, czy też przystąpienia do organizacji już istniejącej.

Na marginesie należy zauważyć, iż pomimo zmiany stanu prawnego jeszcze nie upowszechniła się możliwość przynależności do organizacji związkowych osób świadczących 
pracę za wynagrodzeniem na innej podstawie niż stosunek pracy; również statuty związków utrzymują zasadę dopuszczalności jednoczesnej przynależności również do innych organizacji. Sytuacja decyzji odmownej po otrzymaniu deklaracji przystąpienia do organizacji nie jest zatem czysto hipotetyczna.

Przykładowo zgodnie z zapisami $\$ \$ 8$ i 9 Statutu NSZZ „Solidarność” (2018b) oraz treścią uchwały Komisji Krajowej nr 2/06 ws. członkostwa, jego kontynuacji oraz zawieszenia członkostwa w NSZZ „Solidarność” w przypadku osób pozostających w stosunku pracy członkostwo w związku może być realizowane tylko przez przynależność do organizacji zakładowej obejmującej swoim działaniem pracodawcę, u którego ta osoba jest zatrudniona. Członkostwo w związku nabywa się z chwilą rejestracji organizacji zakładowej lub międzyzakładowej lub z chwilą przyjęcia deklaracji członkowskiej uchwałą komisji zakładowej lub międzyzakładowej (władza wykonawcza organizacji związkowej). Władza wykonawcza organizacji zakładowej przed przyjęciem nowych członków zatrudnionych u pracodawcy dotychczas nieobjętego działalnością tej organizacji ma obowiązek sprawdzić w zarządzie regionu, czy dany pracodawca nie jest objęty działalnością innej organizacji zakładowej. Komisja zakładowa lub międzyzakładowa podejmuje uchwałę w sprawie przyjęcia lub odmowy przyjęcia w poczet członków organizacji zakładowej lub międzyzakładowej, której jest władzą, w terminie nie dłuższym niż 30 dni od daty założenia deklaracji przez kandydata na członka. Odmowa przyjęcia w poczet członków wymaga pisemnego uzasadnienia. Statut przewiduje również stosowną procedurę odwoławczą w przypadku odmowy przyjęcia lub bezczynności w wymaganym terminie.

Jak wynika z powyższego, szczegółowy zakres danych osobowych zawartych w deklaracji członkowskiej dostępnej na stronie internetowej związku (NSZZ „Solidarność” 2018a), takich jak nazwisko i imię, PESEL, adres zamieszkania (miejscowość, kod pocztowy, ulica, nr domu, nr lokalu), telefon czy adres e-mail, jest uzyskiwany przez osoby działające $\mathrm{z}$ ramienia określonego ogniwa związkowego, jeszcze zanim dana osoba zostanie przyjęta w poczet członków. Nie są to jednak dane szczególnej kategorii i podstaw prawnych ich przetwarzania należy poszukiwać nie w art. 9, a w art. 6 RODO.

Organizacje związkowe zdają się jednak niewłaściwie interpretować podstawy prawne przetwarzania danych osobowych zamieszczonych w deklaracji członkowskiej, opierając ich przetwarzanie na przesłance zgody. Pomijam już w tym miejscu kwestię czysto techniczną, budzącą wątpliwości z punktu widzenia zasad udzielenia zgody określonych w RODO, polegającą na złożeniu jednego podpisu pod deklaracją odnoszącą się do różnych oświadczeń i zgód. Istotną kwestią, na którą powinny zwrócić uwagę organizacje związkowe, jest zakres danych osobowych, jakie są przez nie wymagane do wypełnienia w deklaracji. Wydaje się, iż stosowane wzory nie pozwalają podmiotowi danych na pominięcie określonych pól, a jednocześnie z uwagi na zasadę ograniczenia celu i minimalizacji danych możliwość taka powinna się pojawić. Mam tu w szczególności na myśli dane kontaktowe, w ramach których dość powszechnie wymaga się zarówno pełnego adresu zamieszkania, telefonu, jak też adresu e-mail. Co więcej, w deklaracjach członkowskich niektórych organizacji jako dana osobowa, której podania się wymaga podczas przystępowania, widnieje płeć (Konfederacja Pracy 2018), czego 
zasadność również należałoby rozważyć, mając na względzie zasadę minimalizacji przetwarzania danych osobowych oraz ograniczenia celu chociażby z tej przyczyny, że podawany jest również PESEL.

Na przykładzie deklaracji członkowskiej NSZZ „Solidarność” (2018a), składając podpis na deklaracji, pracownik zarówno deklaruje wstąpienie do związku, jak też oświadcza, że będzie stosował się do postanowień statutu związku, w szczególności zobowiązuje się do regularnego opłacania składek związkowych oraz wyraża zgodę na potrącanie składki z wynagrodzenia, zgodę na przetwarzanie danych osobowych w związku z realizacją celów statutowych NSZZ „Solidarność” oraz zgodę na przetwarzanie danych w celu wydania legitymacji elektronicznej, a ponadto potwierdza, że otrzymał klauzulę informacyjna zgodną z RODO stanowiącą załącznik do deklaracji członkowskiej NSZZ „Solidarność”.

Stanowiąca załącznik do deklaracji członkowskiej NSZZ „Solidarność” klauzula informacyjna jako administratora danych osobowych zawartych w tejże deklaracji wskazuje. jako jedną z możliwych opcji do wyboru, organizację zakładową, międzyzakładową, podzakładową lub oddziałową. Co więcej, „Współadministratorem danych osobowych w zakresie niezbędnym do wydania deklaracji elektronicznej jest właściwy Region NSZZ «Solidarność» [...]”. Jak to już zostało zaznaczone we wstępnej części niniejszego opracowania, właściwe zidentyfikowanie relacji współadministrowania jest w praktyce niezwykle trudne. Co więcej, samo poinformowanie podmiotu danych o współadministrowaniu jego danymi osobowymi nie jest wystarczające. Jak to było już wcześniej wskazane, zgodnie z art. 26 RODO w drodze wspólnych uzgodnień współadministratorzy w przejrzysty sposób określają odpowiednie zakresy swojej odpowiedzialności dotyczącej wypełniania obowiązków wynikających z RODO, w szczególności w odniesieniu do wykonywania przez osobę, której dane dotyczą, przysługujących jej praw, oraz ich obowiązków w odniesieniu do podawania informacji, o których mowa w art. 13 i 14, chyba że przypadające im obowiązki i ich zakres określa prawo unijne lub prawo państwa członkowskiego, któremu administratorzy ci podlegają. W uzgodnieniach można wskazać punkt kontaktowy dla osób, których dane dotyczą. Nie dysponując szerszym zakresem informacji odnośnie do wspólnego ustalania przez organizację zakładową, międzyzakładową, podzakładową lub oddziałową i właściwe regiony celu i sposobu przetwarzania danych osobowych objętych wnioskiem o wydanie legitymacji elektronicznej, nie można przesądzić jednoznacznie, czy wskazanie takie jest poprawne, czy też nie. $Z$ uwagi jednak na to, iż wniosek o przyjęcie w poczet członków związku $z$ autonomicznym zakresem danych osobowych składany jest $w$ regionie, może pojawić się wątpliwość, czy nie jest on w tym zakresie autonomicznym administratorem. Tożsamość danych osobowych, jakie są wymagane do złożenia wniosku o wydanie legitymacji elektronicznej NSZZ „Solidarność”, z tymi, które są przekazywane podczas wypełnienia deklaracji członkowskiej, nie przesądza jeszcze o współadministrowaniu tymi danymi.

W bardzo zbliżony sposób została sformułowana treść zarówno samej deklaracji członkowskiej, jak i zgód na przetwarzanie danych oraz klauzuli informacyjnej w NSZZ „Solidarność" 80 (2018). Katalog współadministratorów został dodatkowo poszerzony 
o Komisję Krajową NSZZ „Solidarność” 80. W odróżnieniu od informacji przedstawianej przez NSZZ „Solidarność” nie zostało jednak nawet wskazane, w jakim zakresie i jakimi danymi osobowymi podmioty te współadministrują.

Godzi się zaakcentować, iż w przypadku szeregu organizacji związkowych udostępniających swoje dokumenty na stronach internetowych dość powszechne jest powoływanie się na zgodę jako podstawę prawną przetwarzania danych osobowych zawartych w deklaracji członkowskiej. Zgoda ta często jest łączona z realizacją celów statutowych, na przyklad: „Wyrażam zgodę na przetwarzanie moich danych osobowych zawartych w deklaracji dla potrzeb realizacji celów statutowych". Moim zdaniem, z uwagi na obowiązki informacyjne zakładowych organizacji związkowych, a także możliwość sądowej weryfikacji liczby członków z ostatniego dnia danego półrocza nie jest możliwe opieranie przetwarzania danych osobowych zawartych w deklaracjach członkowskich na podstawie zgody, która - jak wiadomo - może być cofnięta w dowolnym czasie. Nie wpływa to, oczywiście, na zgodność z prawem przetwarzania, którego dokonano na podstawie zgody przed jej wycofaniem, ale trudno byłoby sobie wyobrazić skuteczne cofnięcie zgody na przetwarzanie danych zawartych w deklaracji z zachowaniem statusu członka organizacji. W przypadku byłych członków może być również konieczne wykazanie, iż w dniu składania przez organizację związkową informacji o liczbie członków osoba taka była jej członkiem. Podstawą do przetwarzania danych osobowych członków i byłych członków, w mojej ocenie, powinny być cele statutowe i przepisy prawa nakładające na organizację określone obowiązki - zarówno sprawozdawcze, jak i weryfikacyjne (art. $25^{1}$ u.z.z.).

\section{Podsumowanie}

Pobieżna analiza stosowanych przez organizacje związkowe klauzul informacyjnych adresowanych do swoich członków pozwala na postawienie tezy o braku jednolitości w zakresie określenia relacji zachodzących pomiędzy podmiotami danych a poszczególnymi ogniwami struktur związkowych.

Mając na uwadze obowiązki, jakie spoczywają na administratorze danych osobowych, oraz konsekwencje prawne ich niewykonywania, struktury związkowe powinny jak najszybciej uporządkować przepływy danych, określić sposoby przetwarzania danych oraz wzmocnić zabezpieczenia. Przesyłanie informacji ujawniających przynależność związkową drogą mailową niejednokrotnie na ogólne adresy e-mail należące do organizacji związkowych, do których dostęp ma zwyczajowo przyjęty krąg osób, bez jasno stosowanego kryterium niezbędności do realizacji celu, może generować poważne ryzyko dla organizacji, również finansowe. W praktyce ruchu związkowego organizacje niejednokrotnie silnie akcentują poufność w zakresie przynależności swoich członków. Aby w pełni realizować tę maksymę, powinny bezwzględnie zrewidować sposoby przechowywania dokumentacji oraz przepływów danych, zwłaszcza wówczas gdy korzystając z infrastruktury pracodawcy, przekazują sobie dane e-mailem, nie stosując żadnych środków zabezpieczających. 
Dla realizacji celów statutowych przetwarzanie danych osobowych zawartych w deklaracji członkowskiej od dnia przejęcia danej osoby w poczet członków bez wątpienia powinno się odbywać właśnie na podstawie przesłanki określonej w art. 9 ust. 2 pkt d RODO. Jedynie gdyby organizacja związkowa zamierzała ujawnić dane o członkostwie danej osoby, a ujawnienie to nie znajdowałoby oparcia w wypełnianiu obowiązków i wykonywaniu szczególnych praw przez administratora lub osobę, której dane dotyczą, w dziedzinie prawa pracy, zabezpieczenia społecznego i ochrony socjalnej (art. 9 ust. 2 lit. b RODO), wymagana będzie zgoda podmiotu danych.

\section{Bibliografia}

Baran K.W. (2019a) [w:] K.W. Baran (red.), Zbiorowe prawo zatrudnienia. Komentarz, Warszawa. Baran K.W. (2019b) Prawo związków zawodowych do informacji po nowelizacji ustawy zwiqzzowej, „Monitor Prawa Pracy”, nr 1.

Barta J., Fajgielski P., Markiewicz R. (2007) Ochrona danych osobowych. Komentarz, Kraków. Drozd A. (2008) Ustawa o ochronie danych osobowych. Komentarz. Wzory pism i przepisy, Warszawa.

Fajgielski P. (2018) Ogólne rozporzadzenie o ochronie danych. Ustawa o ochronie danych osobowych. Komentarz, Warszawa.

Gałęzowska K. (2019) Współadministrowanie danymi osobowymi - wybrane problemy prawne

[w:] T. Wyka, M. Mielczarek (red.), Administrator i inspektor ochrony danych osobowych. Pozycja prawna, Warszawa.

Konfederacja Pracy (2018) Deklaracja członkowska, https://konfederacjapracy.org.pl/jak-zalozyc-zwiazek-zawodowy/deklaracja-czlonkowska (dostęp: 12.08.2019).

Książek D. (2019) [w:] K.W. Baran (red.), Zbiorowe prawo zatrudnienia. Komentarz, Warszawa.

Mednis A. (1997) Ochrona danych osobowych w konwencji Rady Europy i dyrektywie Unii Europejskiej, „Państwo i Prawo”, nr 6.

Mednis A. (1999) Ustawa o ochronie danych osobowych. Komentarz, Warszawa.

NSZZ „Solidarność” 80 (2018) Deklaracja członkowska, https://www.solidarnosc.org.pl/slupsk/ deklaracja_czlonkowska.pdf (dostęp: 12.08.2019).

NSZZ „Solidarność” (2018a) Deklaracja członkowska, http://www.solidarnosc.org.pl/images/ files/deklaracja_czlonkowska_2018.pdf (dostęp: 12.08.2019).

NSZZ „Solidarność" (2018b) Jednolity tekst statutu NSZZ „Solidarność, po wprowadzeniu zmian uchwalonych przez XXIX krajowy zjazd delegatów NSZZ „Solidarność” w dn. 25 października 2018 r., http://www.solidarnosc.org.pl/dokumenty/statutowo-wyborcze/statut/ statut (dostęp: 12.08.2019).

Sibiga G. (2003) Postępowanie w sprawach ochrony danych osobowych, Warszawa.

Sobczyk A. (2019) Przedsiębiorca a pracodawca wewnętrzny - problematyka przetwarzania danych osobowych pracownika, „Monitor Prawa Pracy”, nr 5.

Związek Nauczycielstwa Polskiego (2018) Deklaracja członkowska, https://znp.edu.pl/druki-formularze/deklaracja-czlonkowska-znp (dostęp: 12.08.2019). 